\title{
BLACKBRUSH, COLEOGYNE RAMOSISSIMA Propagation and Revegetation OF Disturbed Sites
}

\author{
HARRISON HUGHES • EUGENE WEGLINSKI \\ DEPARTMENT OF HORTICULTURE \\ COLORADO STATE UNIVERSITY $\bullet$ FORT COLLINS
}

\section{- INTRODUCTION}

Blackbrush (Coleogyne ramosissima Torr.) is a small to medium sized shrub of the Rosaceae family. It is considered to be a paleoendemic species which once disturbed on a site does not reestablish. Its distribution is a narrow band ranging from eastern California to extreme western Colorado occupying a niche between the major species of the Great Basin and Mojave Deserts (Bjugstad 1983; Landis and Simonich 1983; and Wallace et al. 1970). The populations at Arches and Canyonlands National Parks occupy the northern most region of its range.

Guidelines exist for the propagation of blackbrush by seed (Vories 1981). Problems exist, however, with the acquisition of seed due to infrequent and inconsistent seed set and establishment of seedlings due to feeding by herbivores (Bowns and West 1976). Therefore, asexual propagation by cuttings or mound layering offer potential. Asexual propagation techniques may present the answer to the revegetation problem in that a relatively large number of plants may be produced with a minimal amount of effort once a successful methodology is established. Additionally, rooted cuttings result in a mature plant more rapidly than do seedlings, reducing the mortality problem due to herbivore feeding. Finally, mother plants which are well adapted to a specific site may be reproduced, increasing the probability of success once the plantlets are reintroduced into the field. There were three primary objectives of this research. The first was to evaluate the effects of rooting hormones, season, and maturity of the wood on the rooting of cuttings of blackbrush. The second, was to evaluate response of blackbrush to mount layering with mother plants receiving normal or supplemental water. Finally, we evaluated the reintroduction of all plantlets to the field using proper planting times, soil preparation, and water harvesting techniques. The ultimate goal was to establish procedures for propagating blackbrush and reestablishing it onto disturbed sites within the National Parks.

\section{- MATERIALS AND METHODS}

\section{SITE DESCRIPTIONS}

This study was conducted over a period of two years and involved five study sites. Sites were located within the Island in the Sky district of Canyonlands National Park, Moab, Utah. Precipitation in this region ranges from 150 to 200 $\mathrm{mm}$ and is highly variable over small areas. Total precipitation over the duration of the study was 170 $\mathrm{mm}$ in 1988 and $115 \mathrm{~mm}$ in 1989. Annual temperatures range from $-26^{\circ} \mathrm{C}$ to $42^{\circ} \mathrm{C}$. Sites were selected based on their proximity to disturbances in various stages of recovery. (See Hughes and Weglinski 1991 for detailed site descriptions and methodology). 


\section{$\checkmark \quad$ RESULTS AND DISCUSSION}

\section{STEM CUTTINGS}

Analysis of variance for the spring and summer collection dates indicated significance only among main effects (age, site, treatment). Age was the only significant factor to affect rooting of cuttings collected in spring. One-year-old growth produced a higher percentage of rooted cuttings, more roots, and longer roots than old growth (Table 1). Data collected from the summer sample resulted in significance of all three main effects on the dependent variables. Cuttings collected in summer showed a similar rooting response to spring collected cuttings in terms of cutting age (Table 2). Younger growth (new and one-year-old) responded better than old growth for all dependent variables. Additionally, new growth produced a higher percentage of rooted cuttings than one-year-old growth. Cuttings treated with hormones produced a higher percentage of rooted cuttings and more roots than cuttings given the

Table 1. Effects of cutting age on the percent of blackbrush cuttings rooted, average roots per cutting and root length for cuttings collected in spring 1989.

\begin{tabular}{|c|c|c|c|}
\hline AGE* & $\begin{array}{l}\text { \% CUTTINGS } \\
\text { ROOTED }\end{array}$ & $\begin{array}{l}\text { AVERAGE } \\
\text { \# ROOTS }\end{array}$ & CLASS \\
\hline New Growth & - & - & - \\
\hline One-Year Growth & 34.00 & $4.00_{2}$ & 2.52 \\
\hline Old Growth & $14.12_{b}$ & $1.70_{b}$ & $1.32_{b}$ \\
\hline LSD $(p<0.05)$ & 8.47 & 1.67 & 0.69 \\
\hline
\end{tabular}

Table 2. Effects of cutting age on the percent of blackbrush cuttings rooted, average roots per cutting and root length for cuttings collected in Summer 1989.

\begin{tabular}{cccc}
\hline AGE* & $\begin{array}{c}\text { \% CUTTINGS } \\
\text { ROOTED }\end{array}$ & $\begin{array}{c}\text { AVERAGE } \\
\text { \# ROOTS }\end{array}$ & CLASS \\
\hline New Growth & $42.50_{\mathrm{a}}$ & $3.87_{\mathrm{a}}$ & $2.55_{\mathrm{a}}$ \\
One-Year Growth & $24.69_{\mathrm{b}}$ & $4.36_{\mathrm{a}}$ & $2.04_{\mathrm{a}}$ \\
Old Growth & $3.75_{\mathrm{c}}$ & $2.50_{\mathrm{b}}$ & $0.53_{\mathrm{b}}$ \\
LSD (p<0.05) & 7.78 & 1.22 & 0.56 \\
\hline
\end{tabular}

* Means within a column followed by the same letter are not significantly different. 
talc control (Table 3). The only difference between hormone treatments occurred with $0.3 \%$ IBA which did not exceed control values in terms of the average number of roots produced. The site at which the cuttings were collected had an effect on the percent of cuttings rooted and root length (Class) with cuttings collected at site 2 outperforming those collected at site 1 (Table 4). There was no difference between the average number of roots produced. Analysis of the date collected in fall resulted in significance of both a treatment effect (Table 5) and a site-age interaction (Figure 1) for the average number of roots produced. Age-site interactions were significant for the percentage of cuttings rooted and root length. Hormone treatments on cuttings collected in fall exceeded control values for the average number of roots per rooted cutting although again no one treatment performed better than the others (Table 5).

Table 3. Effects of treatment on the percent of blackbrush cuttings rooted, average roots per cutting and root length for cuttings collected in Summer 1989.

\begin{tabular}{cccc}
\hline TREATMENT & $\begin{array}{c}\text { \% CUTTINGS } \\
\text { ROOTED }\end{array}$ & $\begin{array}{c}\text { AVERAGE } \\
\text { \# ROOTS }\end{array}$ & CLASS \\
\hline Control (Talc) & $15.62_{\mathrm{a}}$ & $1.41_{\mathrm{a}}$ & N.S. \\
$0.3 \%$ IBA & $27.34_{\mathrm{b}}$ & $1.76_{\mathrm{a}}$ & N.S. \\
$0.8 \%$ IBA & $24.92_{\mathrm{b}}$ & $3.30_{\mathrm{b}}$ & N.S. \\
Rootone & $26.45_{\mathrm{b}}$ & $3.73_{\mathrm{b}}$ & N.S. \\
LSD (p<0.05) & 8.98 & 1.41 & - \\
\hline
\end{tabular}

* Means within a column followed by the same letter are not significantly different.

Table 4. Effects of site on the percent of blackbrush cuttings rooted, average roots per cutting and root length for cuttings collected in Summer 1989.

\begin{tabular}{cccc}
\hline SITE & $\begin{array}{c}\text { \% CUTTINGS } \\
\text { ROOTED }\end{array}$ & $\begin{array}{c}\text { AVERAGE } \\
\text { \# ROOTS }\end{array}$ & CLASS \\
\hline 1 & $19.48_{\mathrm{a}}$ & N.S. & $2.34_{\mathrm{a}}$ \\
2 & $27.73_{\mathrm{b}}$ & N.S. & 0.48 \\
LSD $(\mathrm{p}<0.05)$ & 6.35 & - & 0.48 \\
\hline
\end{tabular}

* Means within a column followed by the same letter are not significantly different. 
Table 5. Effects of treatment on the percent of blackbrush cuttings rooted, average roots per cutting and root length for cuttings collected in Fall 1989.

\begin{tabular}{cccc}
\hline TREATMENT & $\begin{array}{c}\text { \% CUTTINGS } \\
\text { ROOTED }\end{array}$ & $\begin{array}{c}\text { AVERAGE } \\
\text { \# ROOTS }\end{array}$ & CLASS \\
\hline Control (Talc) & N.S. & $1.18_{\mathrm{a}}$ & N.S. \\
$0.3 \%$ IBA & N.S. & $2.29_{\mathrm{b}}$ & N.S. \\
$0.8 \%$ IBA & N.S. & $2.69_{\mathrm{b}}$ & N.S. \\
Rootone & N.S. & $3.00_{\mathrm{b}}$ & N.S. \\
LSD (p<0.05) & - & 0.97 & - \\
\hline Means within a column followed by the same letter are not significantly different.
\end{tabular}

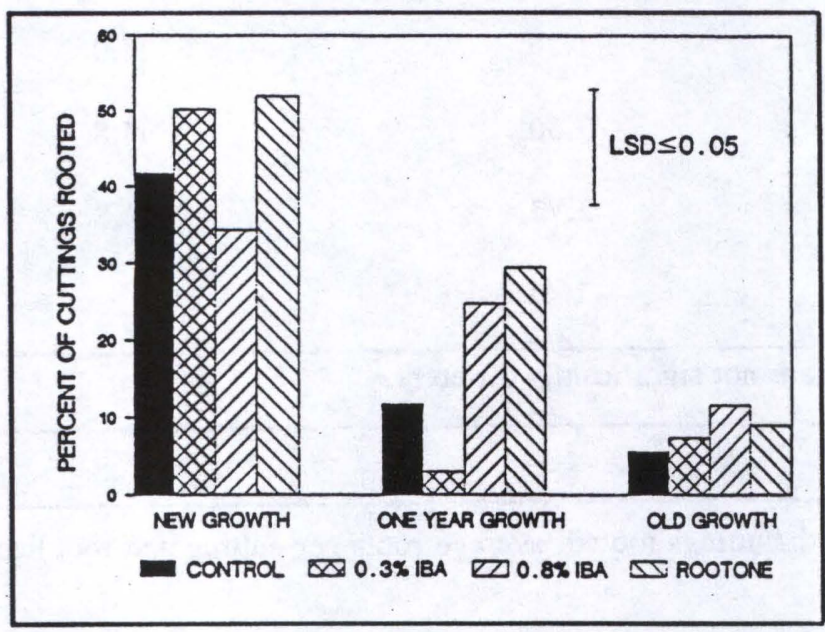

Figure 1. Interaction of age and treatment on the percent of rooted cuttings of blackbrush (Coleogyne ramosissima Torr.) collected in Fall 1989.

Age-site interaction indicates new and one-yearold growth produced more average roots per rooted cutting than older growth. New growth collected from site 2 also produced significantly more roots than new growth collected at site 1. New growth produced a greater percentage of rooted cuttings and longer roots than older wood while one-year-old growth showed an intermediate response. Treatment effects were negligible except for one-year-old growth in both cases. It appears that cutting age has a greater effect than hormone treatment for differences in the rooting response illustrated in Figures 1 and 2. The percentage of cuttings rooted and the average number of roots per rooted cutting of cuttings collected in summer were higher for hormone-treated cuttings. Differences between

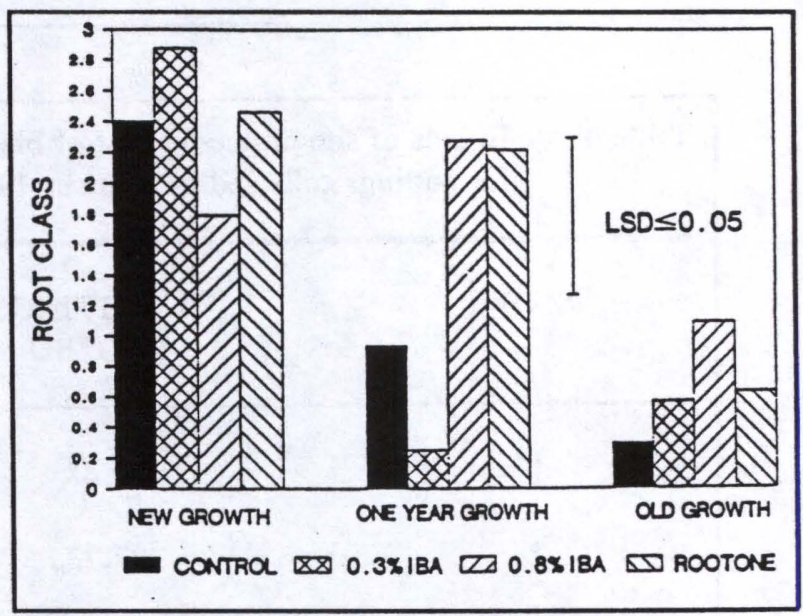

Figure 2. Interaction of age and treatment of root length (CLASS) of blackbrush (Coleogyne ramosissima Torr.) cuttings collected in Fall 1989. 
treatments occurred only with $0.3 \%$ IBA treated cuttings whose values did not exceed the controls for the average number of roots produced (Table 3 ). One-year-old cuttings collected in fall and treated with $0.3 \%$ IBA also failed to exceed control values in the percent of rooted cuttings and root class (Figures 1 and 2). Although the age of the cutting itself is not directly correlated with differences in rooting response, younger wood produced a greater number of rooted cuttings, more roots, and longer roots than older wood at each date. Structural and physiological changes associated with organ age such as lignification and differences in enzymatic activity and auxin levels respectively affect rooting in a number of species (Hartmann and Kester 1983). The nutritional status of stock materials may also have an effect on rooting response in some species. Cuttings taken from tissues which are high in carbohydrates and have a balanced mineral nutrient status root more readily than tissues low in carbohydrates or showing nutrient deficiencies (Hartmann and Kester 1983). Young growth, such as that sampled in this study, is typically a resource sink (Salisbury and Ross 1978) and therefore may be better physiologically suited for rooting than older wood. Differences in rooting response based on site differences were apparent during the summer and fall dates. Cuttings collected from site 2 outperformed those from site 1 in terms of the number of cuttings rooted, root length (Table 4 ), and the average number of roots produced.

The Institute for Land Rehabilitation (1979) found differences in rooting ability of Atriplex between two separate populations as well as among individuals. They speculate that the differences may be a result of environmental or genetic differences. Chase and Strain (1966) and Alvarez-Cordero and McKell (1979) drew similar conclusions based on results from similar experiments with relatively small sample sizes. Although plants at both sites were of similar size and general vigor, it is possible that moisture regimes and phenological stage differed between the two sites resulting in a site effect. Genetic aspects of blackbrush remain uninvestigated.

There were no treatment effects on cuttings collected in spring 1989. Differences did occur in the late sample dates between treatments and the control within some variables. The general result is that rooting hormones increased the rooting response over the controls. IBA at $0.3 \%$ was the only treatment, in some cases, which did not exceed controls. These findings are similar to those reported by Chase and Strain (1966) and Wieland et al. (1971) in that hormone treated cuttings of various species rooted better than controls although hormone concentration was often insignificant. One-year-old growth is apparently in a transition in its ability to produce rooted cuttings. The $0.3 \%$ IBA response on one-year-old growth could possibly be explained in two ways. First, it is possible that rooting cofactors (Hess 1965) may be involved in the change in rooting ability of blackbrush cuttings. Second, it may be that the sample size may not have been large enough to accurately reflect the true rooting response of this material. Blackbrush may be among the plants which have the potential to produce roots but are lacking sufficient amounts of an auxin which must be added exogenously for roots to form. Additionally, it is possible that rooting cofactors are produced only in younger wood which accounts for the poor rooting response of older wood. The objective of the study was to determine optimum conditions for production of rooted blackbrush cuttings. New growth at the semi-hardwood stage was clearly the optimal age for successful rooting. A hormone treatment is beneficial to rooting success, while sample date, although difficult to compare statistically, is likely to affect physiological factors enough to influence rooting. The optimum regime for cutting production as determined by this study is to collect cuttings from current season's growth in early summer and treat cuttings with $0.8 \%$ IBA. An interesting study by Klass et al. (1985) reported that optimizing air temperature, light intensities, and photoperiod had a greater effect than hormonal treatments in rooting mesquite (Prosopis alba). This type of approach might be valuable in propagation studies of species with highly variable rooting responses.

The results from this investigation indicate possible directions for future study. A closer examination of hormone response on younger wood (new and one-year-old growth) might provide further clarification of hormone effects. Additionally, the use of rejuvenated plant material such as that produced in the attempted mound layering study versus typical cutting material may yield valuable results in production of rooted cuttings. Physiological investigations with climatic monitoring might assist in assessing the differences in rooting response between populations at different sites. 


\section{MOUND LAYERING}

Evaluation was completed in November 1988 when the mounded soil was carefully removed and shoots were examined for rooting. Only one plant in the entire study produced a root. The lack of rooting could be attributed to the inability of blackbrush to produce adventitious roots, the lack of vigor of the mother plants, a lack of moisture in the mounding material, or other unforseen possibilities. Fifty-eight of the 60 plants produced vigorous new growth initially following the shoot removal. Plants receiving irrigation visually produced more growth than the nonirrigated plants. All new growth following shoot removal on eight plants (3 irrigated, 5 nonirrigated) eventually died. Varying degrees of mortality were observed in shoots of other plants. Irrigated plants were the most healthy in appearance at the time of final evaluation.

Problems with the delivery system occurred at different times at each of the sites. The drip tubing occasionally became clogged and rodents chewed through some of the exposed tubing at the Grand View Point site. Water ran freely from the damaged tubes depriving the plants fed by those tubes of their regular water supply and causing the barrel to drain faster as a result of the unchecked water flow. Clogged and damaged lines were repaired at the monthly recalibration, however, the plants watered by those particular lines went without water from the time of the problem until the lines were rechecked. Plant mortality was not associated with these interruptions. The study was unsuccessful in its goal of establishing a procedure for mound layering blackbrush. The production of a single root may indicate that conditions around that shoot were conducive for rooting. The appearance of a root might also be explained as an unusual natural occurrence. However, it may indicate that there was insufficient moisture to allow for rooting. Alternatively, it could mean that the stems need girdling after initial development to stimulate rooting as is the case for layering in some plant species (Hartmann and Kester 1983). The study supports the findings of Bowns and West (1976) that removal of older growth to near ground level resulted in a flush of new growth. The success of the cutting aspect of this research indicates this treatment may provide excellent material for cuttings.

\section{REESTABLISHMENT}

The survival of the cuttings throughout the 1989 growing season is summarized in Table 6. More than half of the cuttings died in the first month following planting, while survival apparentlystabilized by mid-summer. Fifteen percent $(4 / 26)$ of the cuttings receiving supplemental irrigation survived through November when the final evaluation was completed. An inspection in March 1990 revealed no additional mortality.

Statistical analysis within the study was not possible as a result of the small sample size. An analysis using Fisher's exact test (Steel and Torrie, 1980) to compare survival of cuttings planted in March 1989 to survival (0/50) of blackbrush seedlings planted at the same site by a private contractor in fall 1988 was made. Fisher's test allows comparison of two unrelated sets of numbers. The two sets of numbers were significantly differentat the 0.05 level. Although there were a great number of variables involved in this comparison, including planting dates, plant material, and planters, one could assume that irrigation influenced the survival rate.

A possible explanation for the initial mortality rate is that the cuttings were barerooted at the time of planting. The potting soil in which the cuttings were planted contained a large percentage of native soil which was not bound by the roots when cuttings were removed from the tube packs. Mortality in bare-root plantings is not uncommon. The Institute for Land Rehabilitation (1979) evaluated the survival of nine shrub and five grass species in containerized versus bare-root plantings on a site in Bonanza, Utah. They reported better survival with containerized plants for both types. They noted that survival and heights of containerized plants after five years were significantly better on harsh sites than that of bare-root plants. They present a review of similar research which indicates various results in comparisons of containerized and bare-root plantings. Although survival of bare-root plantings equals or exceeds that of containerized in some cases, it is likely that this occurrence coincides with more mesic environments. 
Table 6. Survival of Blackbrush (Coleogyne ramosissima Torr.) cuttings over the 1989 growing season.

\begin{tabular}{rccccc}
\hline Date & March 15 & April 17 & June 15 & July 15 & Nov 12 \\
\hline Control & 14 & 3 & 0 & 0 & 0 \\
Irrigation & 12 & 5 & 3 & 2 & 2 \\
$\begin{array}{c}\text { Irigation+ } \\
\text { Agrosoke }\end{array}$ & 13 & 6 & 4 & 2 & 2 \\
\hline
\end{tabular}

\section{$\checkmark \quad$ CONCLUSION}

Stem cuttings proved to be a successful method for asexual propagation of blackbrush. The highest percentage of rooted cuttings within a treatment was nearly $50 \%$. Cuttings taken in summer or fall from current year's growth and given supplemental rooting hormone produced more rooted cuttings with a greater number of roots and longer roots than older cuttings, cuttings collected in spring, or cuttings not given a hormone treatment. Mound layering was not a successful approach for asexual propagation. Plants produced luxuriant growth in response to the mound layering process and supplemental irrigation. This type of new growth was not evaluated for its ability to root; however, it is likely that such growth would root as readily as the new growth reported in this study.

The use of a rejuvenation treatment such as cutting growth back to ground level as in the mound layering process may provide a valuable tool in producing sources material for other methods of propagation. Rejuvenated and irrigated plants in the case of blackbrush produced on the order of ten times more new growth than untreated plants. This approach may be especially useful when source material is limited. The addition of supplemental water also serves to increase growth and vigor of new growth and is likely to increase the success of producing rooted cuttings in species which have the potential to root.

\section{- LITERATURE CITED}

Alvarez-Cordero, E., and C. M. McKell. 1979. Stem cutting propagation of big sagebrush (Artemisia tridentata Nutt.). J. Range Mgmt. 32(2):141-143.

Bjugstad, A. J. 1983. Establishment of trees and shrubs on lands disturbed by mining in the west. In: New Forest for a Changing World. Proceedings of the 1983 Society of American Foresters National Convention. pp. 434-438.

Bowns, J. E., and N. E. West. 1976. Blackbrush (Coleogyne ramosissima Torr.) on southwestern Utah rangelands. Utah Agri. Exp. Sta. Res. Rep. 27.

Chase, V. C., and B. R. Strain. 1966. Propagation of some woody desert perennials by stem cuttings. Madrono. 18:240-243.

Hartmann, H. T., and D. E. Kester. 1983. Plant propagation: principles and practices. PrenticeHall Inc., Englewood Cliffs, NJ. pp. 727.

Hess, C. E. 1965 . Rooting cofactors - identification and function. Int. Plant Prop. Soc. Comb. Proc. 15:181-186.

Hughes, H. and E. Weglinski. 1991. Blackbrush, Coleogyne ramosissima propagation and revegetation of disturbed sites. Final Report to UW-NPS Research Center. Contract 5-32720. 
Available from Canyonlands National Park, Southeast Utah Group, Moab, UT. 37 pp.

Institute for Land Rehabilitation. 1979. Selection, propagation, and field establishment of native plant species on disturbed arid lands. Utah Agri. Expt. Sta. Bull. 500. pp. 49.

Klass, S., R. L. Bingham, L. Finkner-Templeman, and P. Felker. 1985. Optimizing the environment for rooting cuttings of highly productive clones of Prosopis alba (mesquite/algarrobo). J. Hort. Sci. 60(2):275284.

Landis, T. D., and E. J. Simonich. 1984. Producing native plants as container seedlings. In: P. M. Murphy (compiler) The challenge of producing native plants for seedlings. In: $\mathrm{P}$. M. Murphy (compiler) The challenge of producing native plants for the Intermountain area: proceedings: Intermountain Nurseryman's Association 1983 conference. General Technical Report INT-168. U.S.D.A. Forest Service, Intermountain Forest and Range Experiment Station, Ogden, Utah. pp. 96.
Salisbury, F. B., and C. W. Ross. 1978. Plant Physiology. Wadsworth Publishing Co. Inc. Belmont, CA. p. 94.

Steel and torrie. 1980. Principles and Procedures of Statistics: a Biometrical Approach. McGrawHill, New York, New York. pp. 633.

Vories, K. C. 1981. Growing Colorado plants from seed: a state of the art. Vol 1:Shrubs. USDA For. Ser. Gen. Tech. Rep. Int.-103.

Wallace, A., E. M. Romney and R. T. Ashcroft. 1970. Soil temperature effects on growth of seedlings of some shrub species which grow in the transitional area between the Mojave and Great Basin Deserts. BioScience 20(21):11581159.

Wieland, P. A. T., F. Frolich, A. Wallace. 1971. Vegetative propagation of woody shrub species from the northern Mojave and southern Great Basin Deserts. Madrono 21(3):149-152. 